\title{
Effects of Asiasari radix on the morphology and viability of mesenchymal stem cells derived from the gingiva
}

\author{
SU-HYEON JEONG ${ }^{1}$, JI-EUN LEE ${ }^{2}$, SEONG-HO JIN ${ }^{2}$, YOUNGKYUNG KO ${ }^{2}$ and JUN-BEOM PARK ${ }^{2}$ \\ ${ }^{1}$ Department of Rehabilitation Medicine of Korean Medicine, Chungju Hospital of Korean Medicine, \\ College of Korean Medicine, Semyung University, Jecheon 390-711; ${ }^{2}$ Department of Periodontics, \\ College of Medicine, The Catholic University of Korea, Seoul 137-701, Republic of Korea
}

Received November 24, 2013; Accepted June 17, 2014

DOI: $10.3892 / \mathrm{mmr} .2014 .2607$

\begin{abstract}
Medicinal herbs used in traditional Oriental medicine, which have been in use clinically for thousands of years, are attractive sources of novel therapeutics or preventatives. Asiasari radix (A. radix) has been suggested for use in the treatment of dental diseases, including toothache and aphthous stomatitis. The aim of this study was to evaluate the effects of A. radix extracts on the morphology and viability of human stem cells derived from the gingiva. An Asiasarum heterotropoides extract was centrifuged and freeze-dried in a lyophilizer. Stem cells derived from the gingiva were grown in the presence of A. radix at concentrations ranging between $0.1 \mu \mathrm{g} / \mathrm{ml}$ and $1 \mathrm{mg} / \mathrm{ml}(0,0.1,1,10,100$ and $1,000 \mu \mathrm{g} / \mathrm{ml})$. Cell morphology was evaluated with an optical microscope and the viability of the cells was quantitatively analyzed with a cell counting kit-8 (CCK-8) assay for up to seven days. The untreated control group exhibited normal fibroblast morphology. The shapes of the cells following $0.1,1,10$ and $100 \mu \mathrm{g} / \mathrm{ml} \mathrm{A}$. radix treatments were similar to those of the control group. However, a significant change was noted in the $1,000 \mu \mathrm{g} / \mathrm{ml}$ group on day 1 , when compared with the untreated group. Furthermore, on day 7, the shapes of the cells following 100 and $1,000 \mu \mathrm{g} / \mathrm{ml} \mathrm{A}$. radix treatments were rounder and fewer cells were present, when compared with those of the control group. The cultures that grew in the presence of A. radix did not exhibit any changes in the CCK-8 assay on day 2; however, significant reductions in cell viability were noticed following 100 and $1,000 \mu \mathrm{g} / \mathrm{ml} \mathrm{A}$. radix treatment on days 5 and 7 . Within the limits of this study, A. radix influenced the viability of the stem cells derived from the gingiva. Thus, the direct application of A. radix to oral tissues may produce adverse effects at high doses.
\end{abstract}

Correspondence to: Professor Jun-Beom Park, Department of Periodontics, Seoul St. Mary's Hospital, College of Medicine, The Catholic University of Korea, 222 Banpo-daero, Seocho-gu, Seoul 137-701, Republic of Korea

E-mail: jbassoonis@yahoo.co.kr; jbassoon@hanmail.net

Key words: herbal medicine, plant roots, stem cells, cell survival
Therefore, the concentration and application time of A. radix requires meticulous control to obtain optimal results. These effects require consideration, if the use of A. radix is planned for the treatment of dental diseases.

\section{Introduction}

Medicinal herbs, which have been used for thousands of years in traditional Oriental medicine, are attractive sources of novel therapeutics or preventives $(1,2)$. The herbs have been pre-validated for effectiveness and are expected to have fewer safety issues than chemically synthesized drugs (3).

Asiasari radix (A. radix) has been used as a flavoring substance in a wide variety of dietary products, and as an ingredient in drinks, cosmetics, soaps, shampoos, fragrances and herbal products, without reported adverse effects (4). A. radix is termed seshin in Korean, xì xīn in Chinese and saishin in Japanese, and is used for treating pain, allergies and inflammatory disorders in traditional Oriental medicine $(3,5,6)$. A. radix is primarily derived from either Asiasarum heterotropoides or Asiasarum sieboldii (6). Studies has been performed regarding the anti-inflammatory and anti-allergy effects of A. radix $(7,8)$.

A. radix has been suggested for use in the treatment of oral diseases, including toothache and aphthous stomatitis $(9,10)$, as this therapy been suggested to exert antibacterial and anti-inflammatory effects $(3,6)$. However, only limited information is currently available regarding the effects of A. radix on dental tissue (11) and no information is available on the effects on mesenchymal stem cells derived from the gingiva.

The aim of the present study was to evaluate the effects of Asiasarum heterotropoides extract on the morphology and viability of the human stem cells derived from the gingiva.

\section{Materials and methods}

Preparation. The dry roots of Asiasarum heterotropoides (400 g) were immersed in distilled water and boiled under reflux for $150 \mathrm{~min}$. The resulting extract was centrifuged at $5,000 \mathrm{x} \mathrm{g}$ for $10 \mathrm{~min}$, and the supernatant was concentrated to $300 \mathrm{ml}$ using a rotary evaporator under reduced pressure (Eyela NE-1001, Tokya Rikakikai Co. Ltd, Tokyo, Japan). The concentrates were then freeze-dried in a lyophilizer 

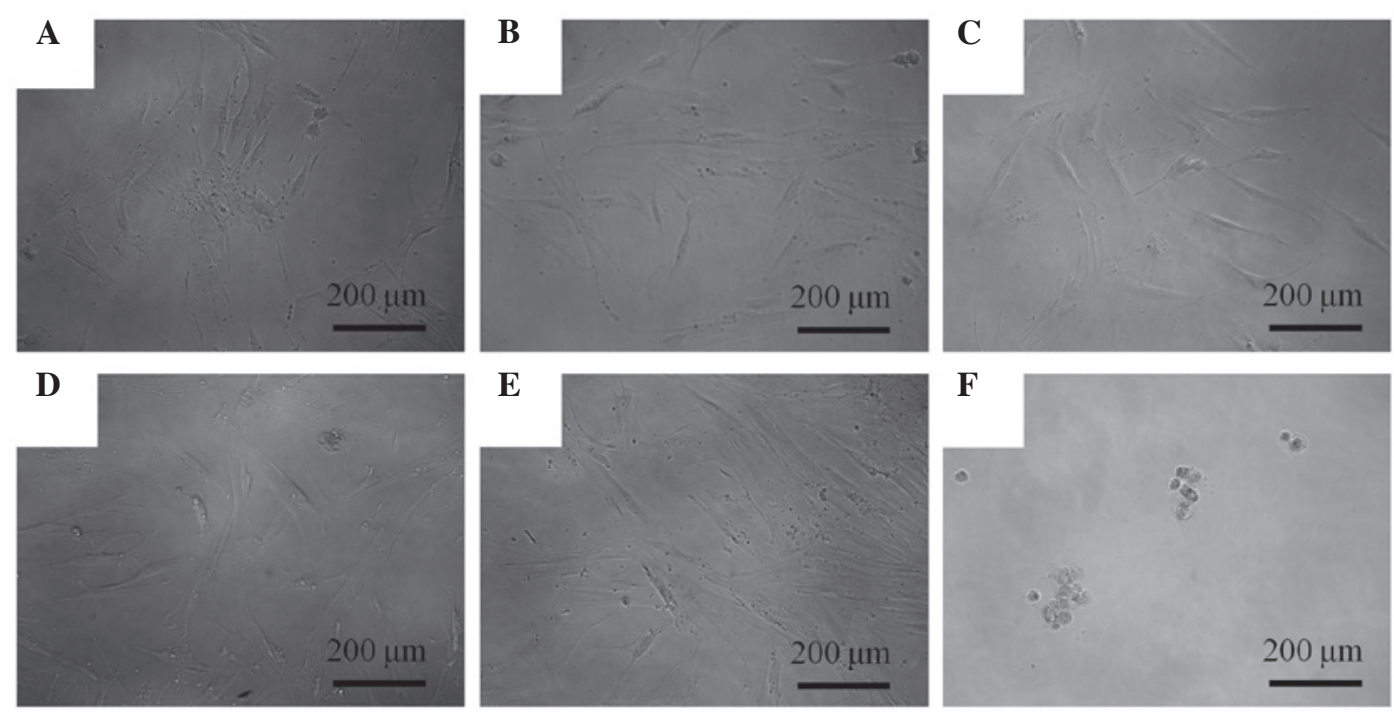

Figure 1. Evaluation of gingival cell morphology on day 1 following: (A) Control, (B) $0.1 \mu \mathrm{g} / \mathrm{ml}$, (C) $1 \mu \mathrm{g} / \mathrm{ml}$, (D) $10 \mu \mathrm{g} / \mathrm{ml}$, (E) $100 \mu \mathrm{g} / \mathrm{ml}$ and (F) $1,000 \mu \mathrm{g} / \mathrm{ml}$ A. radix treatment.

(Labconco, Kansas, MO, USA) to obtain $65 \mathrm{~g}$ solid residue (yield $16 \%, \mathrm{w} / \mathrm{w})$.

Isolation and culture of stem cells derived from the gingiva. Healthy gingival tissue samples were collected from healthy patients undergoing clinical crown lengthening procedures. The design of this study was reviewed and approved by the Institutional Review Board of Seoul St. Mary's Hospital, College of Medicine, the Catholic University of Korea, Seoul, Republic of Korea (KC11SISI0348) and informed consent was obtained from the patients.

The gingival tissue was de-epithelialized, minced and digested with collagenase IV (Sigma-Aldrich, St. Louis, MO, USA). The cells were incubated at $37^{\circ} \mathrm{C}$ in a humidified incubator with $5 \% \mathrm{CO}_{2}$ and $95 \% \mathrm{O}_{2}$. After $24 \mathrm{~h}$, any non-adherent cells were washed with phosphate-buffered saline (Welgene, Daegu, Korea) and fresh medium was added. The media was changed every 2-3 days.

Determination of cell viability. The cells were plated at a density of $2.0 \times 10^{3}$ cells/well in 96 -well plates. The cells were incubated in minimum essential medium- $\alpha$ containing $15 \%$ fetal bovine serum (Gibco-BRL, Carlsbad, CA, USA), $100 \mathrm{U} / \mathrm{ml}$ penicillin, $100 \mu \mathrm{g} / \mathrm{ml}$ streptomycin (Sigma-Aldrich), $200 \mathrm{~mm}$ L-Glutamine (Sigma-Aldrich) and $10 \mathrm{~mm}$ ascorbic acid 2-phosphate (Sigma-Aldrich) in the presence of A. radix at concentrations of: 0 (untreated control), 0, 0.1, 1, 10, 100 and $1,000 \mu \mathrm{g} / \mathrm{ml}$, respectively. 2-(2-methoxy-4-nitrophenyl)3-(4-nitrophenyl)-5-(2,4-disulfophenyl)-2H tetrazolium, monosodium salt (WST-8; Cell Counting kit-8 CCK-8; Dojindo, Tokyo, Japan) was then added and the cells were incubated for $1 \mathrm{~h}$ at $37^{\circ} \mathrm{C}$. The analysis was performed on days 2 , 3,5 and 7 . Viable cells were identified using the CCK-8 assay, which relies on the ability of mitochondrial dehydrogenases to oxidize WST-8 to a formazan product. The spectrophotometric absorbance at $450 \mathrm{~nm}$ was measured using a microplate reader (BioTek Instruments, Inc., Winooski, VT, USA). The experiments were performed in triplicate.
Evaluation of cellular morphology. The morphology of the cells was viewed under an inverted microscope (Leica DM IRM; Leica Microsystems, Wetzlar, Germany) on days 1, 3, 5 and 7. The images were saved as JPEGs.

Statistical analysis. The data are presented as the mean \pm standard deviation. A one-way analysis of variance with post hoc test was performed to determine the differences among the groups using a commercially available program (SPSS 12 for Windows; SPSS, Inc., Chicago, IL, USA). P $<0.05$ was considered to indicate a statistically significant difference.

\section{Results}

Cell morphology. The control group exhibited normal fibroblast morphology on day 1 (Fig. 1A). The shapes of the cells following $0.1,1,10$ and $100 \mu \mathrm{g} / \mathrm{ml} \mathrm{A}$. radix treatment were similar to those of the control group (Fig. 1B-E). A significant alteration was noted in the $1,000 \mu \mathrm{g} / \mathrm{ml}$ group when compared with the untreated group. The shapes of the cells in $1,000 \mathrm{~g} / \mathrm{ml}$ group were rounder and fewer cells were present (Fig. 1F).

The morphology of the cells on day 3 is shown in Fig. 2. The shapes of the cells subsequent to $0.1,1,10$ and $100 \mu \mathrm{g} / \mathrm{ml}$ A. radix treatement remained similar to those of the control group. The morphologies of the cells on days 5 and 7 are shown in Figs. 3 and 4, respectively. Marked alterations in cytoskeletal organization were noticed in the 100 and $1,000 \mu \mathrm{g} / \mathrm{ml} \mathrm{A}$. radix groups. The shapes of these cells were rounder, and fewer cells were present, when compared with those of the control group.

Cellular viability. The CCK-8 results on days 2, 3, 5 and 7 are shown in Figs. 5, 6, 7 and 8, respectively. The cultures growing in the presence of A. radix did not exhibit any changes in the CCK- 8 assays on day 2 and no significant differences were identified among the six groups (Fig. 5). However, on day 3 , a significant reduction in cell viability was observed in the groups with higher concentrations A. radix treatment $(1,10,100$ and $1,000 \mu \mathrm{g} / \mathrm{ml})$, when compared with the cells 

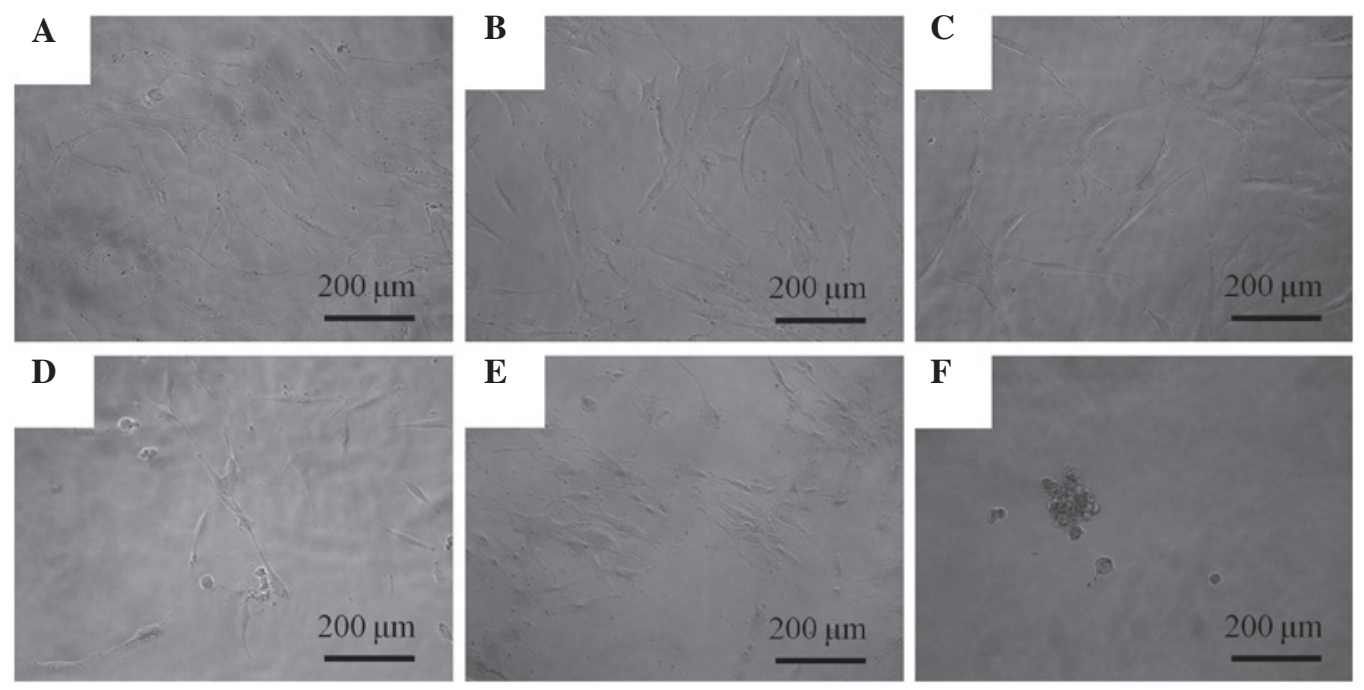

Figure 2. Gingival cell morphology on day 3 following: (A) Control, (B) $0.1 \mu \mathrm{g} / \mathrm{ml}$, (C) $1 \mu \mathrm{g} / \mathrm{ml}$, (D) $10 \mu \mathrm{g} / \mathrm{ml}$, (E) $100 \mu \mathrm{g} / \mathrm{ml}$ and (F) $1,000 \mu \mathrm{g} / \mathrm{ml} \mathrm{A}$. radix treatment.
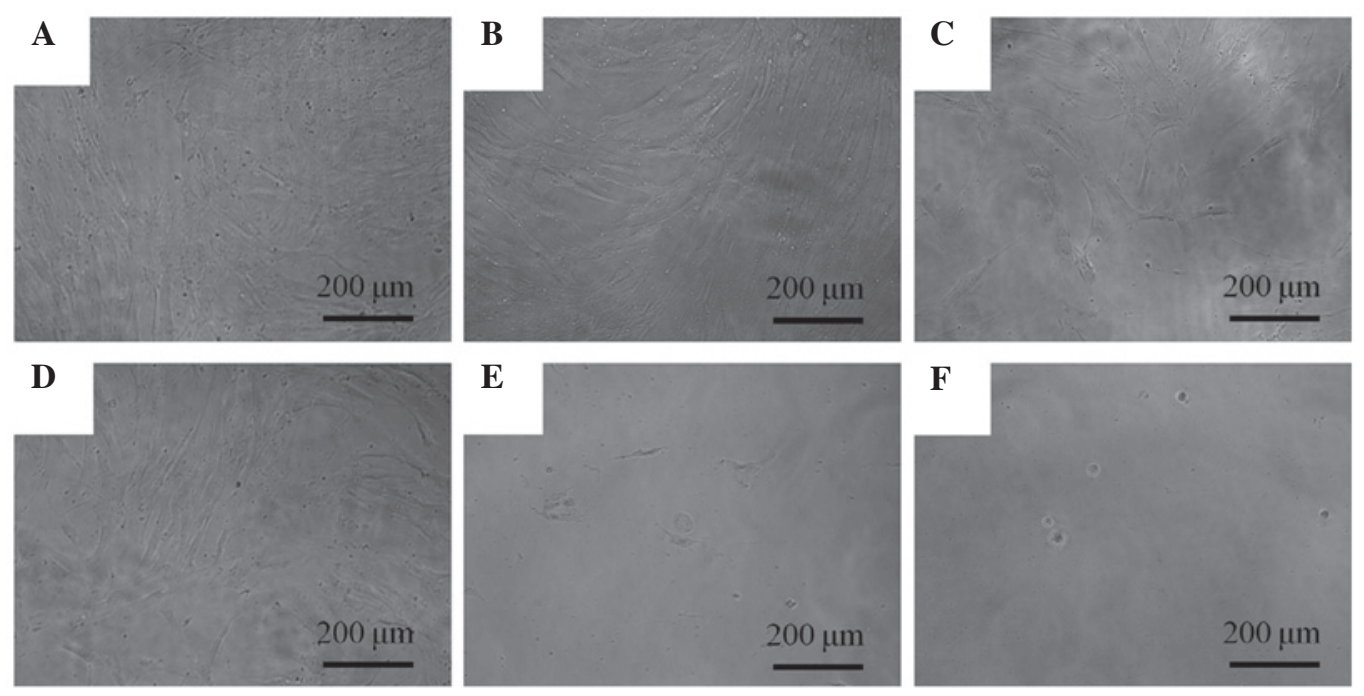

Figure 3. Evaluation of gingival cell shape on day 5 following: (A) Control, (B) $0.1 \mu \mathrm{g} / \mathrm{ml}$, (C) $1 \mu \mathrm{g} / \mathrm{ml}$, (D) $10 \mu \mathrm{g} / \mathrm{ml}$, (E) $100 \mu \mathrm{g} / \mathrm{ml}$ and (F) $1,000 \mu \mathrm{g} / \mathrm{ml} \mathrm{A}$. radix treatment.
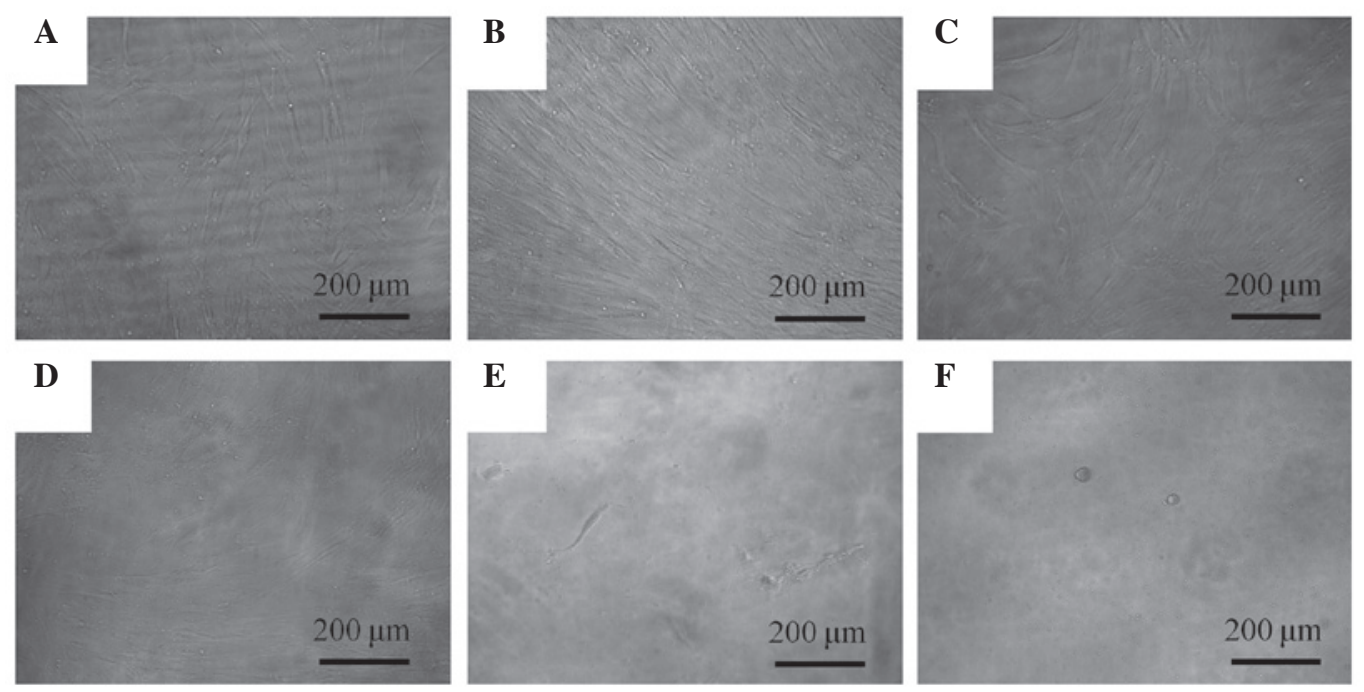

Figure 4. Evaluation of gingival cell morphology on day 7 following (A) Control, (B) $0.1 \mu \mathrm{g} / \mathrm{ml}$, (C) $1 \mu \mathrm{g} / \mathrm{ml}$, (D) $10 \mu \mathrm{g} / \mathrm{ml}$, (E) $100 \mu \mathrm{g} / \mathrm{ml}$ and (F) $1,000 \mu \mathrm{g} / \mathrm{ml}$ A. radix treatment. 


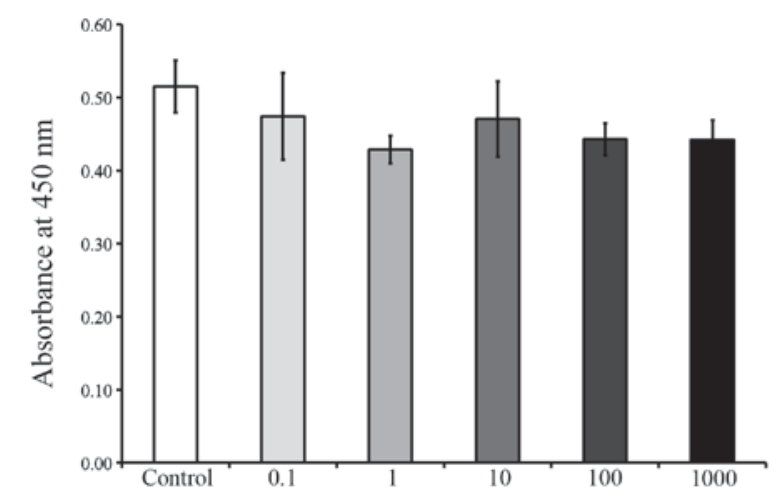

Figure 5. Gingival cell viability on day 2 following $0.1,1,10$ and $100 \mu \mathrm{g} / \mathrm{ml}$ A. radix treatment.

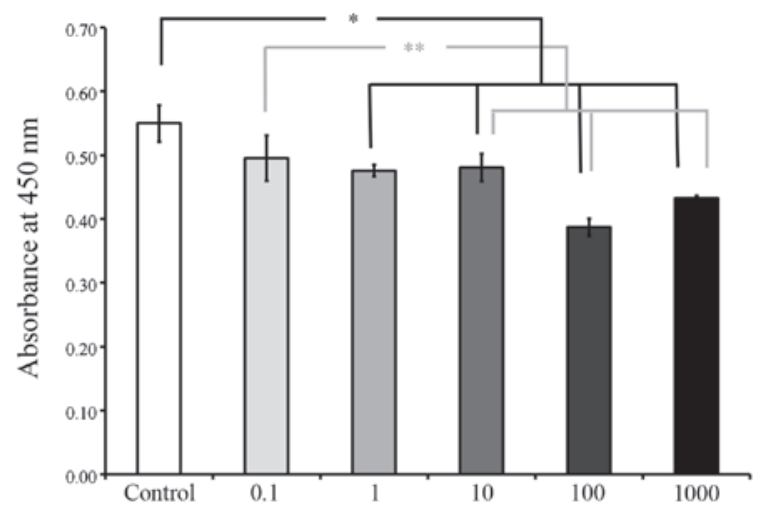

Figure 6. Gingival cell viability on day 3 following $0.1,1,10$ and $100 \mu \mathrm{g} / \mathrm{ml}$ A. radix treatment. $\mathrm{P}<0.05$, as compared with the control group; ${ }^{* *} \mathrm{P}<0.05$, as compared with the $0.1 \mu \mathrm{g} / \mathrm{ml}$ group.

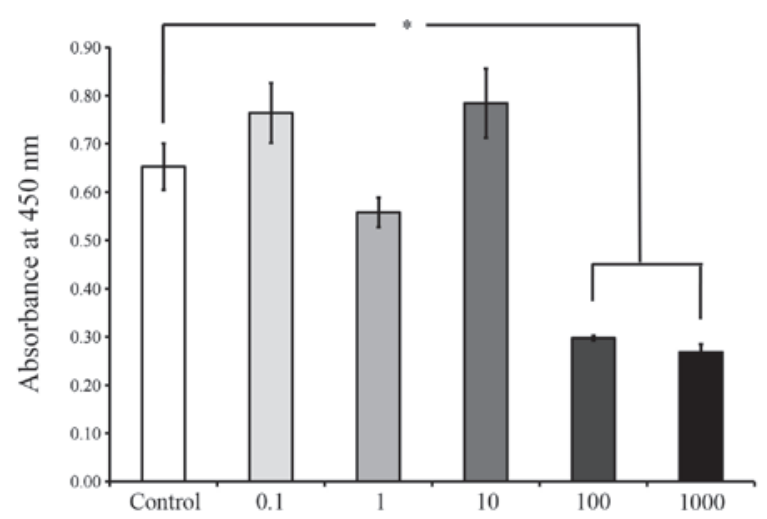

Figure 7. Gingival cell viability on day 5 following $0.1,1,10$ and $100 \mu \mathrm{g} / \mathrm{ml}$ A. radix treatment. ${ }^{*} \mathrm{P}<0.05$, as compared with the control group.

in the control group $(\mathrm{P}<0.05$; Fig. 6$)$. The viability results on days 5 and 7, as shown in Figs. 7 and 8, respectively, revealed significant reductions in cell viability following 100 and $1,000 \mu \mathrm{g} / \mathrm{ml} \mathrm{A}$. radix treatment $(\mathrm{P}<0.05$; Figs. 7 and 8$)$, when compared with the control cells.

\section{Discussion}

In this report, the effects of A. radix on the morphology and cell viability of stem cells derived from the gingiva under

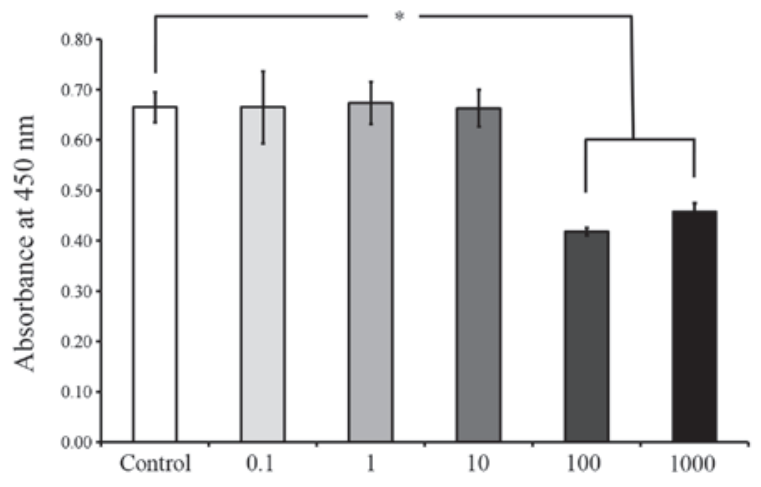

Figure 8 . Gingival cell viability on day 7 following $0.1,1,10$ and $100 \mu \mathrm{g} / \mathrm{ml}$ A. radix treatment. ${ }^{*} \mathrm{P}<0.05$, as compared with the control group.

predetermined concentrations were examined. High concentrations of A. radix exerted adverse effects on the gingival stem cells, and a significant reduction in cellular viability was observed at 100 and $1,000 \mu \mathrm{g} / \mathrm{ml} \mathrm{A}$. radix concentrations.

The effects of A. radix have been previously analyzed in in vitro and in vivo experiments $(4,12,13)$. One study revealed no significant effect on the growth of HeLa cells following A. radix treatment for $72 \mathrm{~h}$ at a range of concentrations between 0.0001 and $1,000 \mu \mathrm{g} / \mathrm{ml}$ (12). The safety of an A. radix methanol extract was investigated in an oral sub-acute 28-day toxicity study in Sprague-Dawley rats at doses of 50,250 and $500 \mathrm{mg} / \mathrm{kg} /$ day, and the authors concluded that the methanolic extract of A. radix appeared to be safe and nontoxic within the experimental conditions (4). The acute oral toxicity of A. radix methanol extract was evaluated in ICR mice; the results revealed no cases of mortality, signs of toxicity or abnormalities in the gross findings (13). The authors concluded that the methanol extract of A. radix was toxicologically safe for oral administration. However, the results of the present study demonstrated that gingival cells treated with 100 and $1,000 \mu \mathrm{g} / \mathrm{ml}$ A. radix exhibited cell damage with significant reductions in cell viability on days 3,5 and 7 . The conflicting results regarding the different responses to A. radix may, in part, be attributed to the type of cells, culturing period or culturing conditions (14).

In the present study, a CCK- 8 assay utilizing water-soluble tetrazolium salt- 8 was used to evaluate the viability of the gingival cells. MTT (3-(4,5-dimethylthiazol-2-yl)-2,5-diphenyltetrazolium bromide) is reported to be a more sensitive assay than trypan blue (15), which is determined by the principle that viable cells have intact cell membranes that exclude the trypan blue dye (16). Dead cells absorb trypan blue and appear blue as a consequence, as the cell membranes are unable to control the passage of macromolecules. The MTT assay determines cellular viability by determining mitochondrial dehydrogenase activity; however, further treatment is required to solubilize the formazan crystals and the MTT agent may be toxic to the cells (17). CCK-8 assay has been reported to be more sensitive than the MTT assay and less toxic to cells (17).

Increasing interest has been generated in the potential of stem cells, which are promising candidates for the regeneration of tissues and the treatment of diseases (18). Mesenchymal stem cells (MSCs) may be isolated from various tissues, including bone marrow (19), adipose tissue (20) and 
muscle (21). Recently, MSCs have been identified in various oral tissues, including dental pulp (22), the lamina propria of the oral mucosa (23) and the periodontal ligaments (24). These tissues may not be easily accessible or obtainable (25); however, the gingiva is easily accessible in dental clinics and, as this tissue is discarded in routine periodontal surgery, may be utilized for the isolation of human MSCs. Thus, stem cells derived from the gingiva may be useful in the investigation and treatment of disease.

A. radix, a traditional herbal medicine commonly used to treat various diseases, has been reported to be safe and nontoxic in previous studies $(4,13)$. A. radix has been shown to treat dental diseases $(9,10,26)$; however, limited information is available regarding the optimal dosage. The present study provided clarification with regard to these issues. A. radix was shown to influence the viability of stem cells derived from the gingiva, with reduced viability at higher concentrations. Therefore, the direct application of A. radix to oral tissues may produce adverse effects at high doses. Thus, the concentration and application time of $\mathrm{A}$. radix requires meticulous control to obtain optimal results.

\section{Acknowledgements}

The present study was supported by the Basic Science Research Program, through the National Research Foundation of Korea funded by the Ministry of Science, ICT \& Future Planning (NRF-2014R1A1A1003106).

\section{References}

1. Lee KH: Research and future trends in the pharmaceutical development of medicinal herbs from Chinese medicine. Public Health Nutr 3: 515-522, 2000.

2. Feng Y, Wu Z, Zhou X, Zhou Z and Fan W: Knowledge discovery in traditional Chinese medicine: state of the art and perspectives. Artif Intell Med 38: 219-236, 2006.

3. Oh SM, Kim J, Lee J, et al: Anticancer potential of an ethanol extract of Asiasari radix against HCT-116 human colon cancer cells in vitro. Oncol Lett 5: 305-310, 2013.

4. Ramesh T, Lee K, Lee HW and Kim SJ: Subacute toxicological evaluation of Asiasari radix methanol extract. Drug Chem Toxicol 32: 243-251, 2009.

5. Jeon HC, Rho EJ, Kim HR and Yun YG: A study on application of Radix Asari main blended prescription from Dongeubogam. Korean J Oreint Med Prescription 12: 57-76, 2004 (In Korean).

6. Jang JY, Lee JH, Shin HK, et al: Partially purified Asiasari radix inhibits melanogenesis through extracellular signal-regulated kinase signaling in B16F10 cells. Int J Mol Med 25: 287-292, 2010.

7. Kamei T, Kondoh T, Nagura S, et al: Improvement of C-reactive protein levels and body temperature of an elderly patient infected with Pseudomonas aeruginosa on treatment with Mao-bushi-saishin-to. J Altern Complement Med 6: 235-239, 2000.
8. Kim HM and Moon YS: Asiasari radix inhibits immunoglobulin E production on experimental models in vitro and in vivo. Immunopharmacol Immunotoxicol 21: 469-481, 1999.

9. Han Y and Kim SJ: Memory enhancing actions of Asiasari radix extracts via activation of insulin receptor and extracellular signal regulated kinase (ERK) I/II in rat hippocampus. Brain Res 974: 193-201, 2003.

10. Kim KS, Kim NS, Kim SD, et al: Regulatory effect of inflammatory reaction by Asiasari radix. Korean J Orient Physiol Pathol 19: 779-784, 2005.

11. Zhou RH (ed): Resource Science of Chinese Medicinal Materials. China Medical and Pharmaceutical Sciences Press, Beijing, 1993

12. Takara K, Horibe S, Obata Y, et al: Effects of 19 herbal extracts on the sensitivity to paclitaxel or 5-fluorouracil in HeLa cells. Biol Pharm Bull 28: 138-142, 2005.

13. Ramesh T, Lee K, Lee HW and Kim SJ: Acute oral toxicity study of Asiasari radix extract in mice. Int J Toxicol 26: 247-251, 2007.

14. Wang Y, Wang WL, Xie WL, et al: Puerarin stimulates proliferation and differentiation and protects against cell death in human osteoblastic MG-63 cells via ER-dependent MEK/ ERK and PI3K/Akt activation. Phytomedicine 20: 787-796, 2013.

15. Meleti Z, Shapiro IM and Adams CS: Inorganic phosphate induces apoptosis of osteoblast-like cells in culture. Bone 27: 359-366, 2000.

16. Stoddart MJ: Cell viability assays: introduction. Methods Mol Biol 740: 1-6, 2011.

17. Almazin SM, Dziak R, Andreana S and Ciancio SG: The effect of doxycycline hyclate, chlorhexidine gluconate, and minocycline hydrochloride on osteoblastic proliferation and differentiation in vitro. J Periodontol 80: 999-1005, 2009.

18. Sekiya I, Larson BL, Smith JR, et al: Expansion of human adult stem cells from bone marrow stroma: conditions that maximize the yields of early progenitors and evaluate their quality. Stem Cells 20: 530-541,2002

19. Kuznetsov SA, Friedenstein AJ and Robey PG: Factors required for bone marrow stromal fibroblast colony formation in vitro. Br J Haematol 97: 561-570, 1997.

20. Rodriguez AM, Elabd C, Amri EZ, Ailhaud G and Dani C: The human adipose tissue is a source of multipotent stem cells. Biochimie 87: 125-128, 2005.

21. Wada MR, Inagawa-Ogashiwa M, Shimizu S, Yasumoto S and Hashimoto N: Generation of different fates from multipotent muscle stem cells. Development 129: 2987-2995, 2002.

22. Ballini A, De Frenza G, Cantore S, et al: In vitro stem cell cultures from human dental pulp and periodontal ligament: new prospects in dentistry. Int J Immunopathol Pharmacol 20: 9-16, 2007.

23. Marynka-Kalmani K, Treves S, Yafee M, et al: The lamina propria of adult human oral mucosa harbors a novel stem cell population. Stem Cells 28: 984-995, 2010.

24. Nagatomo K, Komaki M, Sekiya I, et al: Stem cell properties of human periodontal ligament cells. J Periodontal Res 41: 303-310, 2006.

25. Yoshimura H, Muneta T, Nimura A, et al: Comparison of rat mesenchymal stem cells derived from bone marrow, synovium, periosteum, adipose tissue, and muscle. Cell Tissue Res 327: 449-462, 2007

26. Hidaka S, Okamoto Y and Liu SY: Natural products effective on the in vitro formation of calcium phosphate precipitates. J Trad Med 26: 201-209, 2009. 